DOI: $10.17805 / g g z .2017 .5 .5$

\title{
США: безответственная риторика и вероломная политика
}

\author{
А. Н. ИЛЬИН \\ ОМСКИЙ ГОСУДАРСТВЕННЫЙ ПЕДАГОГИЧЕСКИЙ УНИВЕРСИТЕТ
}

В статье обосновывается, что вербализуемая американскими лидерами политическая пропаганда выступает наиболее наглядным образцом риторики двойных стандартов, лицемерия и лжи. Американская политика опирается на эту легитимирующую ее риторику. Безответственность и вероломство - характерные черты американской риторики и политики. Автором приведено достаточно много примеров высказанных американскими пропагандистами идеологем и действий США на мировой арене, доказывающих этот тезис. Описаны как геополитические, так и экономические случаи. Анализируется внешняя политика США по отношению к России, Ираку, Сирии, Грузии и Украине.

Ключевые слова: риторика; США; демократия; лицемерие; ложь; Россия; Украина; Ирак; Сирия; Грузия

\section{The USA: Irresponsible Rhetoric and Treacherous Policy}

\author{
A. N. ILYIN \\ OMSK StATE PEDAGOGICAL UNIVERSITY
}

The article explains that political propaganda verbalized by America's leaders is the most illustrative example of the rhetoric of double standards, hypocrisy and lies. American policy is based on its legitimizing rhetoric. Irresponsibility and treachery are characteristics of American rhetoric and policy. The author gives a lot of examples of American propagandists' ideologems and U.S. actions on the world stage, proving this thesis. Both geopolitical and economic events are described. The author examines U.S. foreign policy towards Russia, Iraq, Syria, Georgia and Ukraine.

Keywords: rhetoric; USA; democracy; hypocrisy; lies, Russia; Ukraine; Iraq; Syria; Georgia

\section{BВЕАЕНИЕ}

Проблематика «своего - чужого» крайне актуальна в осмыслении политических проблем глобального мира и в выстраивании социально необходимой политики правительствами национальных государств - особенно в ситуации, когда мир переживает новое геополитическое обострение. Ведь от правильного определения «своих» и «чужих», от верного выбора союзников и противников, от умения увидеть в противнике того, кем он является, а не того, за кого он себя выдает, зависит будущее народов и государств.

Как говорил известный политический деятель (Эта фраза обычно приписывается И. Сталину), у каждой проблемы есть фамилия, имя и отчество. Также они имеются у метапроблем, глобальных по своему геополитическому влиянию. Но те, кому принадлежит авторство глобальных проблем, стараются скрыть трагическую реальность некоей риторикой о желании сделать мир лучше. Более того, используя дихотомию «свой - чужой», эти деятели стремятся выдать себя за «своих» для всего мира. Ведь американские СМИ и риторика пропагандистов внешней политики США изобилуют идеологическими тезисами о том, что эта страна стремится принести мир, свободу, демократию и экономический рост в другие страны, помочь им в выстраивании наиболее оптимальной для общества политической системы. 
Но гуманистически выглядящие фразы, к сожалению, не согласуются с реальными действиями, и потому статус «своего» для всего мира наличествует только в этих фразах, но не в действительной мировой политике и экономике. Сколько бы «цивилизованный» мир в лице прежде всего США ни «включал» свою риторику о стремлении везде принести мир, демократию и процветание, эта риторика давно уже дискредитирована реальными действиями мирового гегемона. Очевидно, что американская риторика теряет свои аргументы, утрачивает базис, который позволял бы ей оставаться хотя бы в минимальной степени убедительной. Однако в целях облегчения реализации выбранной американским истеблишментом внешней политики необходимо продолжать воспитывать общества других стран в парадигме того, что США - это «свой» для всех и каждого субъект, несущий помощь и процветание, и его интересы не противоречат интересам других стран. При этом медийный тренд, направляемый американскими элитами, жестко разделяет мир на «своих» и «чужих». «Своими» представляются те, кто идет в фарватере действительных интересов мирового гегемона, а «чужими» - не только те, кто жестко противоречит этим интересам, но и те, кто всего лишь стремится реализовывать суверенную политику. Россия в 1990-х гг. представлялась «своей», поскольку она забыла о внешней политике, об отстаивании национальных интересов, и практически полностью в экономическом и политическом смыслах соответствовала чаяниям американских элит. Сегодня, когда Россия стала пусть даже частично реализовывать именно свою политическую линию и медленными шагами принялась возвращаться на геополитическую арену, она перешла для Штатов в ранг «чужих».

После победы А. Трампа американские спецслужбы сделали доклад о том, будто Россия оказала влияние на выборы в США. Конечно, это «откровение» было незамедлительно подхвачено мировыми СМИ и, как и полагается, максимально растиражировано. Обвинение в адрес России основано на данных совершенно не авторитетных в информационном плане телепередач и постов в Twitter. Если такое обоснование является достоверным, то не менее достоверным выглядели бы ссылки на надписи, содержащиеся на заборах, стенах университетских туалетов и студенческих парт. Смысл ехидной фразы «На заборах тоже написано» вполне буквально и наглядно воспроизведен в данном обвинении. В целом же понятно, что оно не имеет никакой аргументационной базы. Следует говорить о тотальном дефиците аргументов и доказательств у обвиняющей стороны.

ВЕРОИОМСТВО, ПРИКРЫТОЕ ПСЕВАОИНФОРМАЦИОННОЙ РИТОРИКОЙ: ИРАК

Аанный выпад против России не единичный в своей бездоказательности и абсурдности. Он напоминает многие риторические выверты, которыми прославились американские политики и «свободные» СМИ «цивилизованного» мира. Вспомним, например, таинственную пробирку, которую показали мировой общественности в качестве доказательства наличия у С. Хусейна оружия массового поражения. И, посчитав такую аргументацию достаточной и легитимной, США начали войну в Ираке. Конечно, на словах несли туда свободу, демократию и стимулы для экономического процветания. Но слова и боеголовки - явления разные. Вместо реализации красивых обещаний принесли в страну глубокую архаику и безальтернативность. После интервенции «миротворцев» Ирак превратился в то, что британский социолог 3. Бауман метафорически называл не-местом. Ирак потерял экономику, государственный суверенитет и уверенность в завтрашнем дне, и, конечно, ничего положительного не приобрел. 
В книге У. Энгдаля находим следующие данные. После оккупации Штатами Ирака были открыты границы для импорта (без тарифов, пошлин, проверок или налоговых сборов), началась приватизация. Иностранные компании получили возможность владеть активами иракских предприятий. От әпохи Хусейна остались только выгодные для иностранных захватчиков законы, запрещающие профсоюзы. Иностранные корпорации взяли полный контроль над экономикой Ирака, а США выстроили там свои военные базы. Компании, производящие генно-модифицированные продукты, получили право в течение 20 лет использовать свои семена в иракском сельском хозяйстве. Местным фермерам запретили выращивать традиционные культуры и откладывать на следующий посев свои же семена. Фермеров вынудили подписывать соглашение с компанией-держателем патента на ГМО, предусматривавшее выплату «технологического взноса» и ежегодных лицензионных отчислений за культивирование патентованных семян. Иракские фермеры, пытавшиеся сохранить часть патентованных «Монсанто» или другими компаниями семян для посадки в последующие за первым урожаем годы, стали объектами серьезных взысканий. Так фермеры обрели вассальную зависимость от ТНК под громогласную риторику о свободном рынке. Они были вынуждены покупать новые семена каждый год. В целом Ирак обязали следовать программе МВФ, которая передавала экономику страны под руководство вашингтонской администрации (см.: Энгдаль, 2009). А где же стабильность, демократия и экономическое развитие?

Никакого химического оружия «миротворцы»в Ираке не нашли, равно как и не доказали причастность Хусейна к «Аль-Каиде» (организация запрещена на территории РФ как террористическая). Получается, их изначальная риторика была не верна. Ведь они совершили военную интервенцию для уничтожения оружия, которого не оказалось. И никто не понес ответственности за пропагандистскую ложь, на основе которой Ирак был уничтожен. Но это неважно для «цивилизованного» мира; важно то, что российские хакеры своими кибератаками повлияли на выборы в США.

\section{АЖИВАЯ РИТОРИКА И НЕ СООБРАЗУЮЩАЯСЯ С НЕЙ ПОАИТИКА: ИГИА И СИРИЯ}

Череда мифов «made in the USA» связана с предпринятой Россией бомбежкой террористов ИГИА (организация запрещена на территории РФ как террористическая) на территории Сирии. США стремятся уже несколько лет свергнуть Б. Асада. Когда «внезапно» появилось ИГИА, американцы постулировали необходимость борьбы с этим формированием, но при этом их сильно нервирует противостояние Асада этим террористам. Только почему-то Штаты не торопились бомбить ИГИА, не предпринимали против него никаких активных действий. Призывают бороться, но ничего не делают. И стоило России устроить погром этих террористов, США и западная пресса снова стала поливать грязью Россию, которая действовала вполне по заветам Вашингтона. Вашингтон сказал «надо бороться с ИГИ »- Россия борется. Почему же она снова в немилости? Почему монополию на борьбу с ИГИ И имеют только Штаты и их сателлиты, которые, правда, боевой активностью не отличились? Наконец, Россия в Сирии присутствует по просьбе Асада. Америка туда вмешивается без всякого приглашения.

Западно-американская пресса не преминула заявить, что, мол, Россия не тех бомбит. Ну да, не тех, если в реальности американские политики и не думали воевать с ИГИА. В прессе стали появляться заявления, будто Россия в Сирии бомбит не ИГИА, 
а мирную оппозицию. Это как? Оппозиционеры - не анклав территориально отчужденных людей. Они интегрированы в общество, они не отделены от него территориально. Они не базируются в какой-то отдельной части страны. Как же их можно бомбить? Мировая пресса принялась кричать, что якобы в результате российских авиаударов гибнут мирные жители. Причем никаких реальных доказательств предоставлено не было. Однако когда Штаты бомбили Югославию, Ирак, Аивию, подкормленная или просто подневольная мировая пресса не сожалела о мирных жителях, хотя доказательств их массовых убийств было предостаточно. В этих странах подвергали бомбардировкам не террористические организации, а сами страны, и либеральных проамериканских журналистов это не смущало. Так, при вмешательстве ЕС и НАТО в Аивии погибло около 10 тыс. именно гражданских лиц (Иванов, 2012). Однако если событие не показано по телевидению, оно перестает быть событием. Отсутствие телекартинки нейтрализует факт в глазах миллионов людей, не увидевших его на своих экранах.

Американцам позволительно наносить авиаудары по кому угодно, а России нельзя бороться даже с теми, кого сами Штаты называют террористами. Штаты не могут не принять участие в ликвидации ИГИ $\Lambda$, так как они же призывали к этой борьбе. Но и принимать участие тоже нельзя, поскольку террористы американцам выгодны как фактор дестабилизации ситуации в регионе и как убойная сила против неугодного Америке Асада. Америка натолкнулась на серьезное противоречие - особенно когда Россия проявила свою авиаактивность. Осталось только снова инициировать процесс очернения России - уже на почве ее борьбы с ИГИ .

После этого американцы ввязались в войну против ИГИ $\Lambda$, но - вот незадача вместо авиаударов по группировкам террористов в сентябре 2016 г. нанесли удар по противостоящей террористам сирийской армии. И заявили, что ошиблись (см.: Гридин, 2016: Электронный ресурс). Конечно, ошиблись, особенно если учесть, что тем, кто желает свергнуть Асада, ИГИ $\Lambda$, стремящееся к той же цели, - не враг, а друг. Страна, имеющая статус сверхдержавы, обладающая хорошей разведкой, вдруг ошиблась. И просто признала «ошибку», не потрудившись взять на себя ответственность и обязательства. Сирия, видимо, должна удовлетвориться этим признанием, без выдвижения всяких претензий, и никто, получается, не должен платить за содеянное.

Неужели Сирия не имеет теперь права сделать то же самое в отношении США, после чего гордо заявить об ошибке и, конечно, извиниться? Естественно, не имеет, ведь совершать агрессию может только мировой гегемон, и его агрессия априори легитимна. Интересно, что бы произошло, если бы какая-нибудь недружественная страна ударила по американской военной базе, после чего просто заявила: мол, извините, ошибка вышла? Явно разразился бы международный скандал, во всех мировых (подконтрольных Штатам) СМИ кричали бы об акции терроризма, американцы бы заклеймили агрессора во всех смертных грехах, не потрудившись порефлексировать на тему своих преступлений перед человечеством. Ао этого они «ошиблись» в Ираке, когда страну разбомбили, но доказать связь Хусейна с «Аль-Каидой» и найти химическое оружие не смогли. Так, может быть, Штаты - это постоянно ошибающееся государство? В таком случае они просто не могут претендовать на роль мирового гегемона, взявшего на себя право нести в мир свободу и демократию. А вообще, весьма хитрая позиция - сначала натворить дел непотребных, а потом ссылаться на ошибку. Так можно всегда (что Америка и делает) бомбить «не тех», устраивать приводящие 
к обнищанию населения цветные революции в разных странах, подминать под себя целые государства, подсаживать народы на экономические уловки, а затем, после проявленного результата этих действий, говорить: «Мы ошиблись».

Похоже, американские спецслужбы сами создали, спонсировали и продолжают спонсировать ИГИА. Это более чем вероятно, особенно если учесть давно доказанные факты, что американцы ранее вооружали моджахедов в Афганистане для вовлечения советской армии в афганскую ловушку - это признали 3. Бжезинский (Brzezinski et al., 1998: Электронный ресурс; Brzezinski, Garfinkle, 2008: Электронный ресурс), Г. Киссинджер (Киссинджер, 1997) и С. Хантингтон (Хантингтон, 2003). Также стоит вспомнить, что США спонсировали настроенных против России чеченцев, поддерживали «Аль-Каиду» и сами же устроили провокацию 11 сентября, чтобы появился повод войти в Ирак и Афганистан. Такая многоаспектная дружба с «исламским миром» говорит о многом. Ну а теперь ИГИА. После этих действий великой «демократической» державы явно не выглядит убедительной фраза «мы ошиблись и сожалеем», и не представляется аутентичным призыв бороться с ИГИ

Тем более, как отмечается, боевики организации «Исламское государство Ирака и Аеванта» в 2012 г. прошли подготовку под руководством инструкторов из США на секретной базе в Иордании. Эта информация была опубликована американским новостным порталом World Net Daily. Также агентство Reuters, ссылаясь на немецкий еженедельник Der Spiegel, в марте 2013 г. заявило о подготовке боевиков сирийской оппозиции на военных базах в Иордании. Согласно немецкому изданию, за 3 месяца с начала 2013 г. было подготовлено примерно 200 человек. США планировали обучение 1200 членов «Свободной сирийской армии». Британское издание Guardian в марте 2013 г. предоставило информацию, что в подготовке сирийских боевиков на территории Иордании также участвуют инструкторы из Франции и Германии (см., например: США подготовили ..., 2014: Электронный ресурс).

В интервью «Kölner Stadt-Anzeiger» полевой командир «Ажабхат Фатх аш-Шам» (организация запрещена на территории РФ как террористическая) рассказал, как США поддерживают их группировку в борьбе с правительством Асада: Штаты поставляют им оружие и предоставляют военных экспертов. По словам командира, материальную и консультативную поддержку боевикам оказывают еще Турция, Катар, Саудовская Аравия и Израиль (Kolner Stadt-Anzeiger ..., 2016: Электронный ресурс).

Председатель Народного совета Сирии Хадия Аббас сказала, что атака американцев на позиции сирийской армии была намеренной. Удары ВВС США по Аейр-эз-Зору и последующее наступление на этот город боевиков «Исламского государства» были скоординированы. По словам Аббас, после ударов США американские военные связались с ИГИА и рекомендовали террористам как можно скорее начать атаку (см.: В Аамаске заявили ... , 2016: Электронный ресурс; Аамаск заявил ... , 2016: Электронный ресурс).

Также в прессе можно найти сообеение, что с одобрения Вашингтона Саудовская Аравия предоставляла финансовую и другую помощь различным группировкам Сирии, чтобы ослабить правительство Б. Асада (см.: Хаос и экстремизм ..., 2014: Электронный ресурс). Явно эти группировки - не светские мирные оппозиционеры, преисполненные гуманизма и страждущие исключительно о демократии и правах человека. Наконец, американский конгрессмен Т. Габбард заявила в одном из интервью CNN, что CША через страны типа Саудовской Аравии снабжают деньгами и оружием группировки, работающие с «Аль-Каидой» и ИГИА. Понятно, что формулировка 


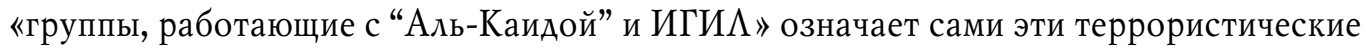
объединения.

7 апреля 2017 г. США нанесли ракетный удар по сирийской авиабазе, которая использовалась для борьбы с ИГИА. Сделано это было под надуманным предлогом борьбы с Асадом, применяющим химическое оружие. При этом - как обычно - не было обнародовано никаких данных, доказывающих предпринятую сирийским правительством химическую агрессию. Американские обвинители и их европейские прислужники не проводили никакого расследования, не выезжали на место, но всячески противостоят инициативе расследования с российской стороны. Без следственных действий «стряпать» обвинение - верх цинизма и некомпетентности.

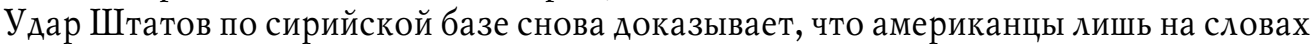
борются с террористами, а на деле помогают им противостоять правительству Сирии; совершенный американцами акт агрессии только помог боевикам ИГИ $\Lambda$ начать наступление. Если такая агрессия - не помощь террористам, то что? Получается, крайне агрессивное противостояние надуманной сирийской химической агрессии по сути является прямой поддержкой террористов ИГИА. Но такая поддержка должна тщательно скрываться, поэтому используются идеологические ухищрения, совершенно не обладающие доказательной базой, построенные на нелепых, ничем не обоснованных, обвинениях. Точнее, они обоснованы исключительно желанием американских элит уничтожить тех, кто не торопится подчиниться геополитическому гегемону; понятно, такое обоснование вполне реалистично, но не обладает никаким легитимационным капиталом. Следовательно, требуется обоснование нереалистичное, необоснованное (здесь такая тавтология вполне уместна), однако хотя бы худо-бедно легитимирующее действия американцев - конечно, если забыть про отсутствие доказательной базы у обвинения в адрес Асада. В общем, обвинение как бы легитимирует действия США (ведь борьба с химическим оружием - дело святое), но только при условии, что забывается полное отсутствие у обвинения доказательного капитала.

Возникает резонный вопрос: почему ИГИА не угрожает Израилю, который является идеологически неверным? Может быть, ответ в том, что Израиль - давний союзник США, на откровенно террористическую деятельность которого мировой гегемон постоянно закрывает глаза? Если же бойцы ИГИА такие независимые от мирового гегемона, при этом антиамерикански настроенные, они явно должны представлять собой угрозу для Израиля. Но, видимо, израильтянам нет повода беспокоиться.

США в конце октября 2016 г. рассматривали возможность поставок сирийской оппозиции продвинутых вооружений для их использования против авиации РФ, чтобы - в конце концов - свергнуть Асада (см.: Аивеева, 2016: Электронный ресурс; Аунаевский, 2016: Электронный ресурс). Но переговоры затормозились - и не потому, что американцы вдруг осознали непотребность своих действий - ведь они оказывают помощь террористам. Объяснение намного прагматичнее и лишено всякого морального подтекста; просто эти поставки способны вызвать эскалацию напряженности с Россией и могут оказаться бессмысленными, поскольку Москва активно вмешалась в сирийскую проблему.

Поддерживаемую Штатами сирийскую оппозицию американцы называют умеренной. Это естественно - ведь, если они признаются в своем обхаживании откровенных головорезов-террористов, возникнет сомнение в том, что действия Америки согласуются с ее риторикой о демократизации мира. Однако, если умеренная оппозиция готова принимать и использовать средства противовоздушной обороны, то она, мягко 
говоря, не совсем умеренная. И кто еще может это делать, как ни ИГИ $А$ Явно не мирные оппозиционеры, деятельность которых ограничена ненасильственными акциями типа пикетов и митингов, принимают и используют продвинутое оружие против авиации. Впрочем, если вглядеться вглубь истории США, то умеренными друзьями Вашингтона в свое время считались такие кровавые диктаторы, как Сухарто в Индонезии и Пиночет в Чили.

Хотели бы американцы ликвидации террористов чужими руками - молились бы на Россию, которая освобождает немалую часть мира от агрессивного фундаментализма. Если бы действительно Штаты желали уничтожить ИГИА, давно бы это сделали самостоятельно и пожинали лавры мирового уважения как борцы против террористов, отрезающих головы мирным людям. Но ИГИА им нужен, а призывы о необходимости его уничтожения - всего лишь ширма. Разрастающаяся террористическая группировка (если дать ей возможность роста) вполне может дестабилизировать регион окончательно, двинуться к странам СНГ и подойти к российским границам. Это нам явно не нужно. А вот для американцев, играющих одновременно против Сирии и России, такое стечение событий вполне выгодно. Бомбежки ИГИА Россией - это как возможность помочь Асаду, так и профилактика возможных конфликтов в будущем. Но в медиа «цивилизованного» мира господствует иная точка зрения.

8 января 2017 г. глава Пентагона Э. Картер назвал «нулевым» вклад РФ в борьбу с ИГИА и заявил, что Россия только разжигает гражданскую войну в Сирии. Это заявление - не более чем очередной лишенное эмпирической основы пропагандистское очернение противника не потому, что он не прав, а потому, что он противник. РФ внесла колоссальный вклад в борьбу с ИГИА, и этот факт неоспорим. Однако (что подтверждается множеством фактов) Штаты внесли огромный вклад в борьбу ИГИА против Сирии как страны, против Асада как ее руководителя, против гуманистических ценностей, против части цивилизованного человечества. Представитель страны, имеющей отрицательный вклад в борьбу против террористов, высказывает претензию в нулевом вкладе к стране, реально совершившей массу антитеррористических действий; лицемерие, возведенное в степень. Учитывая действительные протеррористические действия США, они имеют право критиковать нас не за (несуществующее) отсутствие противостояния «Исламскому государству», а за само противостояние. Намного более честной была бы фраза типа: «Россия виновата в том, что бомбит террористов». Но честность и привычная американская риторика - вещи несовместные.

Пресс-секретарь премьера Великобритании заявила, что Россия препятствует поставкам британской гуманитарной помощи в Алеппо (Brown, 2016: Электронный ресурс). Проблема только в том, что Туманный Альбион ничего за все время войны так и не поставил сирийцам и, более чем вероятно, не собирался әтого делать. Ведь соли-

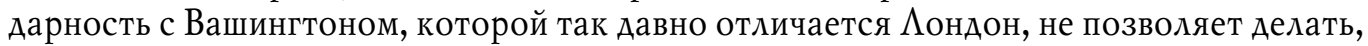
что угодно - в частности, заниматься собственно гуманистической деятельностью. Зато она позволяет заниматься гуманизмом на словах - и заодно ругать Россию, никак не подтверждая свои обвинения. Недаром представитель Минобороны РФ И. Конашенков в ответ на британские обвинения сказал: «Великобритания за все годы войны в Сирии не выделила ни грамма муки, ни одной таблетки и ни одного одеяла для помощи мирным жителям» (цит. по: Конашенков ..., 2016: Электронный ресурс). И явно она воздержалась от благих действий не потому, что Россия (непонятно, зачем!) воспрепятствовала гуманитарным стремлениям Аондона. 
В марте 2017 г. главнокомандующий Объединенными Вооруженными силами НАТО в Европе американский генерал К. Скапаротти обвинил Россию в поддержке Талибана. Конечно, никаких доказательств он предоставлять не стал. Видимо, их просто нет. Ситуация действительно до предела абсурдная: в условиях, когда существуют многочисленные данные о том, что именно США поддерживали талибов во время советско-афганской войны, а затем они же оказывали помощь «Аль-Каиде» и ИГИ высшие должностные лица «цивилизованного мира» позволяют себе публично обвинять Россию в собственных преступлениях перед человечеством, да еще без всякого предоставления фактов о виновности России. Видимо, «цивилизованный» мир вступил в эпоху тотальной безответственности за слова и действия, в эпоху, когда истеблишмент и СМИ берут на себя право обвинять, не предоставляя никаких весомых аргументов и доказательств вины. Этим они сами себя дискредитируют, расписываясь в том, что их слова больше ничего не стоят. С иронией замечу, что, похоже, в этом и заключается прогрессивность и демократизм - раньше всех вступить в эпоху безответственности, опередить время.

В общем, русофобия набрала обороты в «цивилизованном» мире и стала сопрягаться уже не с мелкими инсинуациями, ложными интерпретациями фактов, а с циничным конструированием фактов и откровенной ложью.

\section{ГРУЗИНСКАЯ АГРЕССИЯ И АМЕРИКАНСКАЯ АОЖЬ}

Вспомним еще один показательный случай вопиющей лжи «цивилизованного» мира, а именно то, что их СМИ говорили, когда вскормленная Америкой Грузия совершила военную агрессию по отношению к Осетии.

За пять лет военный бюджет Грузии возрос с $\$ 30$ млн до $\$ 1$ млрд, перед нападением на Осетию в грузинском министерстве обороны работали американские военные инструкторы и проводились профинансированные Пентагоном грузино-американские военные учения (см.: Михайлов, 2008). Ааже 3. Бжезинский отметил поддержку Штатами независимости Грузии и ее стремление вступить в НАТО, а также написал о том, что США после войны 2008 г. перечислили Грузии $\$ 1$ млрд (Бжезинский, 2013).

Американский политик и политолог П. Бьюкенен называет М. Саакашвили любимцем Вашингтона. Бьюкенен негодует, что США лезут не в свое дело, поддерживают интервенцию Грузии, фальсифицируют данные об этой войне мифами об агрессивном вторжении России, признают Южную Осетию и Абхазию провинциями Грузии (Бьюкенен, 2011: Электронный ресурс). Что бы американцы сказали, если бы Россия признала независимость, например, Калифорнии? Явно такой поворот событий им пришелся бы не по вкусу. Аюбимчик Вашингтона - давно уже очевиден такой статус бывшего грузинского лидера - особенно после того, как американцы его не бросили на произвол судьбы и протолкнули к посту мэра Одессы в постмайданной Украине. Они же пролоббировали американку Н. Яресько на пост министра финансов Украины. Весьма интересно в передаче «Специальный корреспондент» выразился защищающий новый киевский режим американский журналист М. Бом. Когда его спросили: «А у вас есть иностранцы в правительстве США?», он ответил: «Ну мы не Украина». Вот именно - они не Украина, они не позволяют иностранцам входить в состав своего правительства. Однако они внедряют иностранцев в правительства тех стран, которые «наконец-то достигли свободы и демократии», а на самом деле просто потеряли свой суверенитет. Очевидно, такой ответ типичного американского «борца за общечеловеческие ценности» демонстрирует американский эгоизм и лицемерие их риторики. 
Защита Россией Осетии в грузино-осетинском столкновении противоречит интересам неявно выступающих на стороне агрессивной Грузии США. Неудивительно, что власти США сразу потрудились развернуть против России широкомасштабную информационную войну. Внезапно все мировые, а не только американские, «независимые» СМИ буквально заиграли в унисон, демонстрируя стреляющих по Цхинвалу грузинских солдат и называя их русскими.

Агрессоры обвиняли Россию в преступлениях, которые они сами совершили. Натравливанием Грузии на Осетию и ввязыванием России в войну был сформирован очередной повод для обвинения нашей страны в глазах мировой общественности. Провокация удалась, и Россия была опорочена. Если бы Россия не ввязалась в войну, не защитила Осетию, она бы проявила предательство с точки зрения осетин и значительного количества русских и слабость с точки зрения своих геополитических противников, которые воспользовались бы возможностью оказать на Россию еще большее давление. При участии в войне Россия неумолимо представляется агрессором в лагере своих противников и в принципе во всем мире. Была создана своеобразная шахматная вилка, указующая на то, что оба варианта плохи для имиджа нашей страны, но второй предпочтительней.

Американские политические верхи назвали Грузию суверенным государством, в отношении которого Россия якобы инициировала военные действия. Это Грузия суверенное государство? Ее суверенность особо «доказывает» факт инициирования Саакашвили войны с Осетией, которая совсем не нужна грузинскому народу и грузинским национальным интересам. Американцы также заявили о непризнании ими независимости Абхазии и Южной Осетии. Можно подумать, что они признают независимость Грузии, которая находилась под их пятой и руководство которой проявило полную боеготовность идти на преступления ради реализации не своих интересов, а интересов своих хозяев. Аа, на словах американцы признают независимость Грузии, но на деле... Грузия (и далеко не она одна) из национального суверенного государства превратилась в филиал корпоративной власти, в элемент государственности, работающей на инженеров глобальной событийности, в их административный орган. Просто тотальная зависимость от США на их оруэлловском языке называется независимостью.

Американцы заявляли о том, что суверенное государство (подразумевая Грузию) имеет право принимать собственные решения и выбирать союзников; вот только развязавшаяся война не была результатом решения, принятого Саакашвили. Несомненно, суверенное государство имеет право на принятие собственных решений и выбор союзников; поэтому нечего обвинять в недемократичности те правительства, которые этим правом воспользовались, и обвинять не за реальный недемократизм, а именно за использование права на суверенность - независимость от мирового гегемона. Просто с точки зрения Вашингтона человеком считается только тот, кто живет в стране, поддерживающей Штаты. Причем определяют, где демократия, сами американцы, то есть используют крайне субъективный критерий, вполне удобный для политики двойных стандартов. Оценка степени демократичности тех или иных стран осуществляется по критерию их лояльности Штатам; важна не настоящая демократичность, а готовность играть по правилам американского истеблишмента, именно непротивление их военной или экономической экспансии.

Америка и НАТО насаждают гуманизм (буквально насаждают, насильственно причиняют добро и наносят пользу) и обвиняют в античеловечности не тех, кто дей- 
ствительно совершает преступления против человека, а тех, кто противится их эксплуататорской политике и не разделяет «общечеловеческие ценности». Смертную казнь убийц-извращенцев они считают проявлением архаичного варварства, но при этом совершенно не стесняются бомбить целые города с ни в чем не повинным населением - бомбить ради демократии. Если некое правительство отказывает транснациональным корпорациям в возможности работать на своей территории, его в соответствии с двойными западными стандартами обвиняют в преступном неприятии святого либерального фундаментализма.

Когда мир все-таки узнал правду, когда стал известен настоящий агрессор, американские СМИ не потрудились взять на себя ответственность за реализованную ими дезинформацию. Мол, подумаешь, ничего особенного, скоро этот факт просто забудут.

\section{УКРАИНСКОЙ ПААЕНИЕ В РЕААЬНОСТИ \\ И АМЕРИКАНСКАЯ РИТОРИКА ОБ УКРАИНСКОМ ВОЗРОЖАЕНИИ}

На Украине при американской поддержке был совершен государственный переворот - наглый и кровавый. Но медиариторика снова себя проявила во всей красе. Она не рассказывала о том, что называемые западно-американской пропагандой «мирными» демонстранты бросились избивать и забрасывать «коктейлем Молотова» силовиков. Бойцы «Беркута», не получая приказа подавлять восстание, вполне по-демократически стояли и смотрели на устроенную революционерами вакханалию. Впоследствии западно-американские СМИ как по команде лживо заговорили о насилии со стороны спецслужб и полиции. Причем про избиение беркутовцев сторонниками Майдана речь не шла. Ааже когда протестующий на Майдане стреляет в людей, для американских лоббистов он остается мирным демонстрантом. Ведь именно они отличают сообразно своим интересам мирных от агрессивных, диктаторов от демократов. Функционирует основанная на двойных стандартах система координат. В разных странах этой системе доверяют, не усматривая или не желая усматривать в ней явного несовершенства.

Интересно, в какой же демократической стране стянутые войска будут просто смотреть на революционный психоз и ничего не предпринимать? Что сделает американский полицейский или военный, если на него кто-то поднимет руку, не то что бросит бутылку с зажигательной смесью? Он сразу пустит пулю. И никто за это судить его не будет. Американцы жестко подавляли у себя многие мятежи, но когда вопрос встал об Украине, американские СМИ заговорили о насилии со стороны «Беркута», который не подавил Майдан потому, что он его не подавлял. Ааже если бы украинские военные подавили восстание, риторика американских СМИ была бы не менее лицемерна, поскольку прежде чем обвинять других в расправах над «мирными» демонстрантами, хорошо бы сначала посмотреть на себя и вспомнить, например, жестокие расправы над мятежниками в 1967 г. в Аетройте или в 1992 г. в Аос-Анджелесе, избиения участников движения «Захвати Уолл-стрит». И почему-то также на словах ратующие за демократию европейские страны не возмущались практиками, реализуемыми в США над протестующими. Почему-то европейские СМИ не кричали о правах человека.

Стоило только России вполне легитимно присоединить Крым - в соответствии с желанием самих крымчан - мировые СМИ начали кампанию о нарождающейся агрессии русских. И это при том, что в Крыму был проведен референдум, и доказа- 
тельств фальсификаций на нем никто не предоставил, кроме эмоциональных американо-украинских возгласов типа «крымчане голосовали под дулом автомата». Потом родилась шутка, что они под дулом все того же автомата коллективно праздновали присоединение к России. Особенно феерично в своей лживости заявление Обамы, что референдум в Крыму нелегитимен, в отличие от референдума в Косово. Странно, что Обама не помнит одну интересную деталь: референдума в Косово не было.

И вообще, когда в мировых СМИ используют формулировку «самопровозглашенное правительство Аонбасса», самим этим понятием подчеркивают нелегитимность данного правительства; мол, собралась какая-то группа никем не выбранных людей и самостоятельно себя провозгласила. Вспоминая историю, хочется на это ответить фразой «самопровозглашенное правительство США». Когда американцы кричат об аннексии Россией Крыма, следует напомнить о том, как США вероломно отобрали у Мексики Техас. Проводилось ли там что-то похожее на референдум?

Когда была пущена под нож Югославия, американцы говорили о праве наций на самоопределение. Когда же Россия «оккупировала» Крым, они заговорили о недопустимости нарушения территориальной целостности Украины. Но при разговорах о необходимости отделения от России Кавказа и многих других областей американские пропагандисты и русофобствующие либералы почему-то не вспоминают тезис о нарушении территориальной целостности. Стоит России заговорить о постройке где-либо своей военной базы, американцы, имея сотни военных баз в мире, не упустят возможности заявить об агрессивности русских.

Агентство национальной безопасности США следит за миллионами людей с помощью различных интернет-технологий, американские спецслужбы прослушивают телефоны высших европейских чиновников. Это, видимо, нормально. А когда разгоняют митинг в неподвластной Штатам стране - в России или в (прежней) Украине, надо возмутиться что есть мочи. Политическая слабость, безволие и тотальная ошибка В. Януковича состояла не в том, что он стянул «Беркут», а как раз в том, что он отказался разгонять протестующих.

На Майдане появились незамеченные американскими СМИ фашистские флаги и послышались призывы к насилию в отношении бойцов «Беркута», их семей и всех несогласных. Парадоксально, но факт: демократические лозунги смешались с фашистскими, бандеровскими и крайне экстремистскими. После этого странно слышать от революционеров и западных журналистов оправдания, что народ «хотел демократии».

Призывы к насилию легитимируют также насилие в отношении тех, кто к нему призывает. Поэтому неубедительно выглядят тезисы сторонников революции, осуждающие насилие в их адрес. Это напоминает позицию «мы их имеем право бить, а они нас - нет». Не менее странно выглядят тезисы о том, что власть подавляет волю народа. Ведь нет никаких достоверных данных, что в этой революции воплощена воля народа. Нет данных, доказывающих поддержку Майдана со стороны всего народа Украины или его большинства. Напротив, люди призывали разогнать митингующих. Но СМИ «цивилизованного» мира предпочитают собравшихся на Майдане отождествлять с народом Украины в целом.

Когда российские власти приняли сначала мягкие меры по удержанию Украины, американские и европейские политики что есть мочи закричали о неправомерном вмешательстве России в дела независимой страны. И этот крик они подняли несмотря на то, что сами абсолютно вероломным образом вмешивались во внутренние дела Укра- 
ины (и не только - вспомним целый ряд других стран, где США и НАТО позволяли себе творить беззаконие и бесчинства), поддерживая взбесившуюся толпу деньгами и всем необходимым, накаливая ее бешенство, провоцируя против России.

Если американцы и европейцы оказывают воздействие на политический ход Украины, это допустимо. Но если русские стараются мягко противодействовать государственному перевороту, поднимается крик о вмешательстве. Цинизм и лицемерие Запада на знают границ. Те, кто ранее поддерживали абсолютно преступные действия в Югославии, Ираке и Иивии, теперь обвиняют Россию в нарушении международного права. При этом американцев, которые давным-давно не просто нарушили, а уничтожили международное право, обвинять не принято. Когда некоторые украинцы говорят о независимости Украины от России, им предоставляют микрофон, а когда другие представители того же народа призывают к налаживанию добрососедских отношений с Россией, им микрофона не дают, ибо, как выясняется, первый случай указывает на демократическое волеизъявление, а второй - на отжившее, архаичное и тупое имперское сознание. Ну и, конечно, с точки зрения американцев, демократом является тот, кто следует распоряжениям НАТО и США. Аругого критерия демократичности просто нет.

Борьбу властей иных стран против революционеров персоны высшего света США критикуют, но в своих глазах не усматривают бревна. Контрреволюционные действия чужих правительств именуют преступлением против человечества, свои действия такого же характера - вынужденной мерой. Арабо-африканских оранжистов называли героями демократического фронта, протестующих в своей стране - бандитами и беспредельщиками. Акции в Тунисе и Египте именовались прямой демократией, а подобные акции в Британии - преступлением. Значит, в других странах можно и нужно, а у нас - ни в коем случае. Значит, там погромщики борются с фашизмом за демократию, а у нас - с демократией за фашизм. Вот такие двойные стандарты.

\section{НАРРАТИВ АЖИВОСТИ И АВОЙНЫХ СТАНААРТОВ - \\ ОАИН ИЗ ВИАОВ АМЕРИКАНСКОГО ОРУЖИЯ}

Американская геополитика, условно говоря, строится на разных видах влияния: военное оружие, экономические удавки, технологии свержения власти. Однако какой бы способ влияния ни использовался, к нему примешивается с виду презентабельная нарративная концепция, на поверку являющаяся не согласованной с реальностью выдумкой.

Бесчеловечные акции военной мощи против Югославии, Ирака и Иивии никак не коррелируют с международным правом и выходят за рамки добра и зла. Однако для каждой из них была выдумана риторическая сказка. Ааже сами военные акции «цивилизованный» мир называет не иначе как «военным пацифизмом», «гуманитарным милитаризмом», «цивилизованной войной», «мирной агрессией» или «гуманитарной интервенцией»- оцените степень парадоксальности и абсурдности этих понятий. Все подобные наименования - символические категории очевидности - отсылают к оруэлловскому оксюморону «мир - это война», в котором воплощена абсурдизация высшей формы. Однажды Н. Хомский, активно изобличающий американский преступный волюнтаризм и его неприкрытое лицемерие, назвал слово «класс» непроизносимым словом из пяти букв; ведь с точки зрения американской пропаганды классов не существует, а есть лишь одна большая счастливая семья на уровне страны, где все хорошо, люди равны, живут в гармонии и трудятся сообща, правительство обо 
всех заботится и т. А. (Хомский, 2014). Слово «неоколониализм» отлично характеризует действия США и стоящего за ним транснационального капитала на мировой арене. Однако уважаемые интеллектуалы и рукопожатные аналитики просто не имеют права называть американские действия таким образом. Поэтому слово «неоколониализм» - непроизносимое слово из четырнадцати букв.

Множество стран подверглись если не военному вмешательству, то экономическим удавкам: Всемирный банк, Всемирная торговая организация и Международный валютный фонд используются в качестве таранов, уничтожающих национальные экономики. И тут не забывается риторический выверт о том, что данные организации в качестве своей цели ставят развитие национальных экономик. Только почему-то американская пропаганда забывает сказать, что везде, где похозяйничали эти исполины глобализации, наступил экономический спад.

Штаты построили массу военных баз в Европе и на Ближнем Востоке. Неудивительно, что многие правительства поддерживают США. Ведь они этими военными базами в некотором смысле оккупированы. И тут применяется риторический прием о том, что эти базы - средства защиты национальных государств от военной агрессии России, Ирана, Северной Кореи и т. А. Только откуда известно, что Россия, Иран и Северная Корея вынашивают против кого-то экспансионистские планы? С таким же успехом можно было бы легитимировать военные базы в глазах, например, немецкой общественности, заверениями о том, что с их помощью Германия защищается от инопланетного вторжения. Вполне закономерно, что вследствие такой оккупации Европа утратила суверенитет, и поэтому европейские СМИ в значительной мере стали американскими СМИ, которые тиражируют абсолютно лживый идейный контент, до краев наполненный русофобией и американофилией.

Именно Штаты инициируют смены режимов в разных странах с неугодными им правительствами. Это коснулось Грузии, Киргизии, Украины и т. А. Конечно, здесь тоже применяется риторический прием о том, что, мол, мы поддерживаем народы, которые возжелали сбросить диктаторов и коррупционеров и построить демократию. Только ни в одной стране, где была совершена поддерживаемая Вашингтоном революция, не возникло ни демократии, ни экономического роста. Американские СМИ в упор не хотят видеть разгул нацизма в постмайданной Украине и тотальной коррупции, учиненной новым правительством. Они наделили себя правом делать в других странах все, что в интересах Pax Americana, но когда кто-то устроил хакерские атаки против Штатов (и даже доказать эти атаки не удалось), «высший свет» проявил глубочайшее возмущение. Выходит, когда мы устраиваем вероломство в отношении других стран, это демократия, а когда некто это делает против нас, это преступление.

Ни одна страна в мире так нагло не вмешивается в дела других стран. Ни одна так огульно не обвиняет других в преступлениях, которые они не совершали. Никто больше не отходит от международного права с такой последовательностью, когда это касается своих интересов. В книге С. Жижека находим следующие примеры: «...представители Соединенных Штатов требовали от сербского правительства одновременно выдачи подозреваемых в военных преступлениях Гаагскому трибуналу... и подписания двустороннего соглашения с США, обязывающего Сербию не выдавать ни одному международному учреждению... американских граждан, подозреваемых в военных или иных преступлениях против человечности...» (Жижек, 2004: 32-33; курсив источника. - A. И.). Также США оказывали «серьезное давление на хорватское правительство», требуя от него выдачи Гаагскому трибуналу двух хорватских генералов, 
«обвиняемых в военных преступлениях во время столкновений в Боснии» (там же: 33 ). Как отметил С. Жижек, «Конгресс США даже рассмотрел законопроект, разрешающий американским войскам вторгнуться в Гаагу, если суд будет рассматривать дело граждан США» (Жижек, 2003: 81). В общем, США признают законность Гаагского трибунала, но только тогда, когда перед судом оказываются другие.

Попытка (даже несуществующая) вмешательства во внутренние дела Штатов расценивается как несусветная наглость и стремление противостоять американскому вмешательству во внутренние дела той или иной страны воспринимается как не менее наглый вызов демократии и правам человека. США за свои военные, экономические и другие действия заслуживают, пожалуй, самого сервезного обвинения, а не права обвинять.

Важно понимать, что приведенные случаи американской риторики - не какие-то исключения из правил, не выходящие за рамки идеологии случаи, а, наоборот, абсолютно парадигмальные вербальные выходки, на которых и строится само здание пропаганды.

\section{АИЯ СЕБЯ - СВОБОАУ ВЕРОАОМСТВА, АИЯ АРУГИХ - РИТОРИКУ}

Хотя мы не можем назвать У. Бека нашим методологическим союзником, обратим внимание на его мысль о том, что признание американцами «других» равнозначно признанию их сходства с собой, а не отличия. По его мнению, «абсолютистский вариант универсализма США сводится к высокомерному допущению, будто единственно подлинным мусульманином является американский мусульманин. Если же мусульмане, африканцы, арабы, китайцы и женщины ведут себя не по-американски или даже антиамерикански, делается вывод, что у них нет на это санкции и они находятся в плену “антиамериканских предрассудков”, являются скрытыми “расистами”, во всяком случае, порабощены “устаревшим” восприятием самих себя. <...> Оно (правительство США. - А. И.) ориентируется на схему мира, в котором одна страна владеет суперсуверенитетом (догадайтесь, какая именно), а всем остальным суверенитет "даруется" лишь на определенных условиях. Проблема устранения границы между сферами национального и интернационального разрешается в пользу “американского национализма международного”. Антикосмополитический момент здесь заключается в таком обстоятельстве: власти США абсолютистским образом позиционируют себя над всеми границами, одновременно требуя, чтобы все прочие народы и правительства их соблюдали - даже принуждаемые к этому силой, если потребуется. Тем самым оно ставит под удар не только легитимность, но и действенность своего вмешательства. Например, поскольку США категорически отказываются подчиниться нормам разоружения, соблюдение которых во всемирном масштабе сама Америка поддерживает (военными средствами), они тем самым разрушают договорный механизм, в конечном счете являющийся единственно надежной гарантией безопасности американских граждан. Кроме того, противоречие между приверженностью делу всемирной демократии, которому в случае необходимости США готовы служить военными средствами, и пренебрежением демократическими консультациями и сотрудничеством с союзниками невозможно бесконечно замалчивать на внутриполитической арене. Такая гегемонистская односторонность вступает в конфликт с восприятием Америкой самой себя как антиколониальной страны» (Бек, 2008: 186-187).

По Беку, власть надгосударственного уровня должна защищать права людей от государств, и «нарушения гражданских прав со стороны правительств могут быть пре- 
дотвращены лишь в случае, если ограничено действие принципа государственного суверенитета» (там же: 203). Аа, дилемма весьма сильная. С одной стороны, в условиях невмешательства государств и наднациональных институтов в суверенные государственные дела могут возникнуть рецидивы попирающего права человека государственного волюнтаризма. С другой стороны, легитимация вмешательства наднациональных структур в дела государств лишает последние суверенитета со всеми вытекающими последствиями. Тем более мы уже неоднократно видели, как так называемые наднациональные (а по сути подвластные Штатам и функционирующие на благо американской корпоратократии) структуры несли «благо» в мир.

Приведем еще несколько фактов, подтверждающих точку зрения У. Бека. Экономические наднациональные структуры ослабляли экономики стран и целых регионов. Эти глобальные институты в свое время предпочли закрыть глаза на дружбу пропагандирующих демократию американских высших лиц с диктаторами. ОБСЕ активно не видит роста национализма в современной Украине, а также совершенно недемократичные, но выгодные геополитическим интересам Штатов, решения и действия правительства. Примеров можно приводить очень много. Везде, где побывали влекомые идеей демократизации и защиты прав человека американские войска и наднациональные институты, в результате вместо утверждения прав человека, демократии и всеобщего процветания воцарились хаос, экономический спад и нищета. Более того, вооруженным риторикой прав человека и манипулирующим ей структурам вполне под силу в мировых СМИ раздуть идею, что в некоей стране нарушаются права людей, происходят этнические чистки и притеснения меньшинств, когда в реальности этого нет. Вспомним, например, украино-американское словоблудие о притеснении российским правительством в правах крымчан в целом и крымских татар в частности. Во многих источниках отмечается идеологическая нагруженность западных СМИ, когда они в своем стремлении очернить сербов постоянно заявляли о геноциде, устроенном сербами по отношению к албанцам, но про албанскую агрессию эти медиа забывали. И в результате может начаться война за соблюдение прав человека там, где они не нарушались - конечно, она будет вестись за соблюдение прав человека на словах и за интересы мировой корпоратократии на деле. Причем картина международных отношений показывает, что американские лобби имеют право решать, где нарушена права человека, а где - нет, но никто не наделен правом указывать на то, как в самих США правительство утаивает информацию, разгоняет митинги несогласных и т. А. Главный вытекающий из всех этих фактов вопрос: действительно ли следует в таких условиях, с такими особенностями функционирования надгосударственных организаций, доверять им правовую сферу национальных государств?

Функционирующий еще со времени создания Вестфальской системы постулат о нерушимости государственного суверенитета сегодня терпит крах. Ранее сформулированные принципы соблюдения границ и невмешательства в дела суверенных государств, когда носителями прав были государства, сегодня столкнулись с сопротивлением. Теперь пропагандируется идея превосходства прав человека над международным правом, и уже суверенитетом наделяются не государства, а индивиды. Звучит на первый взгляд презентабельно, однако постановка прав человека выше государственного суверенитета - удобная отмычка для ослабления госсуверенитета, которая зачастую функционирует без всяческого достижения цели по утверждению прав человека. Эта цель остается демагогической уловкой; для любых деструктивных в отношении кого-либо действий используется какая-нибудь красивая и гуманистиче- 
ски оформленная фраза. Под риторику превосходства прав человека над государственным суверенитетом реализуется практика примата прав надначиональных структур (играющих на интересь финансовой верхушки США) над начиональной автономией.

Мощные наднациональные силы, на словах отстаивая необходимость роста благосостояния в неразвитых странах, на деле посредством ВТО, МВФ и Всемирного банка обрушают их экономики и завладевают их активами. Международная финансовая система устроена так, что бедные страны мира субсидируют США, инициирующих создание в этих странах неподконтрольных национальным правительствам и подчиняющихся Федеральной резервной системе США центральных банков, которые работают на укрепление доллара в мире. США заставляют правительства покупать американские облигации под малый процент и брать у американских финансовых институтов ссуды под большой процент, что, конечно, невыгодно заемщикам. Так реализуется стратегия жизни за счет других, паразитическое обеспечение собственного благополучия посредством ресурсов, отобранных у разных народов; недаром США потребляют около $40 \%$ мировых ресурсов. Причем исходящая в том числе от американских лидеров и верноподданных интеллектуалов-апологетов их политики пропаганда о необходимости мирового единства, совместной борьбы с рисками абсолютно противоречит реальным действиям глобалистов. В принципе, риторика и решения противоречат друг другу, и основная опора политики Штатов - двойные стандарты.

У себя США не допускают разгула рыночного фундаментализма, полной приватизации системы социального обеспечения и абсолютного свертывания бюджетных расходов, защищают закон о банкротстве, сохраняют субсидии производствам и создают таможенные тарифы, уделяют внимание созданию рабочих мест. В своем доме Штаты защищают госрегулирование, государственное социальное страхование, гарантированный доход пенсионеров и в целом социальную политику, стремятся к экономическому росту и борьбе с безработицей. За рубежом они проталкивают отказ от всего этого. За границей проамериканские (называемые наднациональными) структуры продвигают рыночный фундаментализм, усиленную приватизацию, сокращение бюджетных расходов, отказ от субсидий и тарифов, банкротство рассматривают как нарушение кредитного контракта, вместо создания рабочих мест требуют только борьбы с инфляцией. Провозглашая честную конкуренцию, США отходят от нее: американцы утверждают, что они производят более качественную продукцию, и поэтому любая страна, которая может победить Штаты в конкурентной борьбе на американских рынках, якобы использует нечестные торговые приемы (например, сбывает товары ниже себестоимости). Страна, которая не покупает американские товары, тоже якобы реализует нечестные формы ограничения торговли. Америка превозносит идеологемы правового государства, но проводимая ею внешняя политика учитывает только односторонние интересы и характеризуется отказом от правопорядка на международном уровне. Америка выступает за установление глобальных правил торговой и правовой игры, но сама их постоянно нарушает. Аемократия предполагает отказ от навязывания воли кем-либо кому-либо, но США, ратуя за демократию, повсеместно навязывают свою волю другим странам. Называя себя защитником окружающей среды, США является при этом самым серьезным загрязнителем и, предписывая другим снижать производство отходов, себя такими обязанностями не наделяют: вспомним требующий снижение промышленных отходов (и, соответственно, экономического спада) Киотский протокол, который американцы навязывали повсеместно, но сами 
подписывать отказались. Они же под красивым лозунгом «свободной торговли» требуют от других стран открывать рынки и отказываться от протекционизма, но сами не торопятся к открытию своих рынков и сохраняют протекционистские меры. Штаты позволяют себе односторонние действия, но, когда кто-то берет с них пример, с подачки американских лидеров в мировых СМИ идет поток информации о нарушении международных правил, тирании и т. д. Всеми силами во всем мире поддерживается гегемония именно американского доллара.

Большинство из этих противоречий американской политики широко известны, но некоторым из них дано достойное описание в книге Аж. Стиглица (Стиглиц, 2005). Разве это не игра с двойными стандартами, которая обычно в мире прикрывается громогласной риторикой об общечеловеческих ценностях и демократии?

США, ставя под сомнение необходимость суверенитетов других стран, свой суверенитет охраняют с особым рвением и никому не позволят пытаться совершать у себя «оранжевые революции», финансировать оппозицию, вмешиваться во внутренние дела. Получается, Америке можно, другим нельзя. Критерий демократизма - лояльность интересам американских высших лиц, то есть выражаемый национальными лидерами космополитизм, отход от интересов своего народа. Так, сегодня П. Порошенко, несмотря на свои крайне антидемократические и антинародные деяния, квалифицируется Западом в качестве демократа - именно потому, что интересы своего народа променял на интересы геополитического гегемона, которому и был отдан госсуверенитет Украины. Если страна не выполняет требуемые американским истеблишментом действия (которые в самих Штатах не реализуются), режим в ней объявляется нелегитимным и недемократичным.

Парадокс в том, что те, кто объявил себя гуманистом-демократизатором, не гнушаются навязывать свои эгоистические интересы посредством угроз, запугивания, экономической и военной мощи. А поскольку Европа оккупирована американскими военными базами, и тренды в европейских СМИ подстраиваются под информационный уклон американских медиа, так называемое мировое общество присоединяется к очернению правительств, нелегитимность и недемократичность которых заключаются только в том, что они реализуют суверенную, то есть вступающую в противоречие с интересами американских заправил, политику. Причем в медиаконтенте «цивилизованного мира» США выступают в роли достопочтенного мирового гуманиста-демократизатора, новости подаются в выгодном для него свете, сопрягаясь с огромной долей дезинформации.

Н. Хомский и А. Перкинс в своих книгах (Перкинс, 2005; Хомский, 2014) приводят исчерпывающие данные «черной» истории США, описывая поддержку Штатами диктаторов в Аатинской Америке, совершенно нелегитимное военное и экономическое вмешательство мирового гегемона в дела огромного количества стран. Но, как обычно, все это осуществляется во имя демократии и экономического роста, только в результате на место демократии приходит тирания, а место роста занимает экономический упадок и падение народного большинства в нищету.

В общем, история американских действий и риторических выпадов полна лжи, цинизма, лицемерия и двойных стандартов. Но рефлексия их истеблишменту не нужна, незачем через морально нравственную призму пристально смотреть на самих себя и признаваться в собственных преступлениях. Вместо этого им нужно другое - очернить Россию как можно сильнее только за то, что она присоединила Крым, не отдала Аонбасс на разграбление украинским нацистам, воспрепятствовала Штатам «навести 
порядок» в Сирии. Россия не позволила американцам совершить ставшие традиционными для их истории преступные акты, и поэтому Россию стали в мировых СМИ изображать в виде особо злостного преступника.

Только неувязка получается... Аргументов ведь нет, кроме голословных и воистину детских по степени доказательной глубины нападок. «Мы сказали, что вы виноваты, значит, виноваты, а что-то доказывать - не наших рук дело». С таким же успехом можно обвинить Россию в чем угодно - в убийстве Аж. Кеннеди, в урагане «Сэнди», вплоть до затопления Атлантиды. Чем, собственно, «цивилизованный» мир и занимается, всячески выдумывая и тиражируя новые исключительно русофобские штампы. Однако некоторые из них можно воспринимать отчасти как комплимент. Ведь обвинение во влиянии на американские выборы указывает как минимум на два факта. Вопервых, Россия представляется настолько могущественной, что может оказывать воздействие на «святая святых». Только если бы действительно она была такой, в США победил бы не Трамп (которого пророссийским назвать никак нельзя), а какой-нибудь политик, относящийся к России и другим странам как к равным и желающий покончить с крайне агрессивной внешней политикой США, с властью корпораций и Федеральной резервной системы. Очевидно, такое стечение обстоятельств невозможно. Во-вторых, это обвинение дискредитирует американские системы компьютерной защиты; ведь если российские хакеры смогли перетасовать колоду, куда же смотрели американские охранители этой колоды?

В апреле 2017 г. коллектив американской газеты New York Times получил Пулитцеровскую премию за публикации о влиянии России - в том числе на выборы в США. Какие выводы можно сделать из этого факта?

Во-первых, присуждение такой престижной награды за откровенно клеветнические и совершенно бездоказательные статьи не повышает престижности самой премии и ставит вопрос о политической независимости и/или компетентности комитета премии. Иибо эти люди, находясь под политическим давлением, превращают свою премию в акт политического влияния, что совершенно недопустимо. Аибо же они утратили компетентность и превратились в подобие «научного» коллектива, отдающего первые места абсолютно не отвечающим научным критериям сказкам и легендам. Банально говорить, что такая литературная премия, как минимум, должна присуждаться за обоснованные работы.

Во-вторых, русофобия смещает объективность и становится более значимым критерием для наград и похлопываний по плечу; этот вывод делается далеко не только на основе обсуждаемого - «пулитцеровского» - факта. Посыл «цивилизованному» миру такой: пишите ложь о России - и вы будете уважаемыми и успешными.

B-третьих, к вопросу о той же объективности, хочется спросить: а когда-либо присуждали подобные награды за похожие публикации - только касающиеся влияния американских лидеров на состояние других стран? Ведь работы о том, как после рекомендаций (правильнее сказать - давления) со стороны Минфина США и МВФ экономики других стран были обрушены, обладают достаточной аргументационной базой, в отличие от работ о влиянии Кремля на выборы в Штатах. Огромную степень подтвержденности имеет теория о том, что благодаря «демократическому» вмешательству США в ряде стран произошли революции, после которых в эти страны вместо демократизации пришли обнищание и ослабление госсуверенитета. Но за посвященные этим темам публикации престижные западные премии никто не торопится присуждать. Очевидно, премирование - это некая компенсация за необоснованность 
публикаций. Так создается общественное мнение следующего характера: если этим материалам присуждена такая высокая премия, значит, никакого сомнения в их истинности быть не может. Однако правильная логика иная - если этим материалам присуждена такая высокая премия, значит, возникают серьезные сомнения в действительной престижности премии.

Хотелось бы сказать что-то вроде: «Ну, пошутили разок-другой и хватит». Однако такая снисходительная фраза будет категорически неуместна. Ведь проблема вовсе не в шутке, а в самом наглом стремлении возложить вину на того, кто не виновен. Более того, когда мы говорим о лицемерии и лживости американской риторики, следует помнить другой факт: лицемерна и лжива не только их риторика, но и реальная внешняя политика, которую США реализует в мире и от которой мир содрогается.

Одним из главных в американской политике двойных стандартов является словесный оборот «да, но...»:

- Аа, мы за международное право, но действуем по принципу «оппонентам - закон, себе - свободу игнорировать международные договоры»; мы готовы следовать международному праву, только если оно нам выгодно, в ином случае мы называем его архаичным и устаревшим. Аа, мы обеспокоены нарушениями международного права, но лишь тогда, когда его нарушает наш политический конкурент.

- Аа, мы против терроризма, но называем терроризмом только недружественные акты по отношению к себе, а свои агрессивные действия терроризмом не считаем. Когда мы строим военные базы во всем мире, это для поддержки безопасности человечества, но никому не позволим построить военные базы в своей стране.

- Аа, мы поддерживаем демократию, но только если она не приводит к власти социалистов, анти(альтер)глобалистов и любых, кто против нас. Аа, мы за право суверенного выбора, но позвольте нам суверенно выбирать политическую, экономическую, культурную и социальную форму развития для всех государств, несмотря на то, что при нашем содействии развитие оборачивается упадком. Аа, мы за свободный выбор, но наделяем себя правом оказывать в других странах помощь выгодному нам кандидату, причем совсем непозволительно, если правительства иных стран будут оказывать аналогичную помощь кандидату на выборах в США.

- Аа, мы за свободное самоопределение народов, но только при условии, что оно соответствует интересам американских элит и транснационального бизнеса. $А$ a, мы воздаем должное свободе волепроявления народов, но каждый из них должен поддерживать наше военное, экономическое, политическое (например, инициирование «оранжевых революций») вмешательство в его дела, причем никто не имеет право вмешиваться в наши суверенные дела.

- Аа, мы за либеральный принцип честной конкуренции, но сами наделяем себя правом вершить нечестные деяния в виде подсаживание стран и народов на экономические удавки. Аа, мы за честную конкуренцию, но никому не позволим даже честно конкурировать с военной мощью США и экспансией доллара. Наш либерализм требует от всех государств отказаться от права субсидировать национальный бизнес, но мы оставляем за собой право поддерживать своего производителя. Аа, мы за свободный рынок, но свободный рынок - этот тот, где выигрывают американские (получившие статус транснациональных) корпорации. И если какое-то правительство препятствует интересам американских корпораций, мы его изобличаем как националистическое, диктаторское, антиамериканское, ибо интересы США и интересы корпораций едины; и мы освобождаем народ этой страны от такого правительства. 
- Аа, мы за борьбу против коррупции, но не в США и подконтрольных нам странах. Аа, мы за низвержение коррупции, но готовы у себя принимать коррупционеров, которые боролись ради наших интересов против государств-соперников, и не готовы отдавать их под суд на их родине.

- Аа, права человека - это серьезная проблема неподвластного нам Китая, но не Чили времен Пиночета или Индонезии времен Сухарто.

- Аа, мы за мир во всем мире и против милитаризации, но только мы имеем право наращивать военную мощь и оккупировать своими военными базами другие страны. Если это делает кто-то другой, мы называем его агрессором.

В общем, сами они руководствуются интересами, но всему миру навязывают обязанность руководствоваться идеологией. И эта идеология не выгодна Вашингтону в качестве средства ведения своей политики. Она выгодна Вашингтону в качестве экспортной идеологии, когда ее используют в виде средства ведения политики другие государства.

Аж. Псаки с ее удивительно бредовыми нападками вовсе не является каким-то патологическим исключением из правил. Скорее, медийный контент США подвергся тяжелому заболеванию, пандемии псевдоинтеллектуализма, помноженного на самую циничную ложь. «Феномен Псаки» медленно, но верно становится тенденцией, захватывающей, поглощающей медиапространство «цивилизованного» мира, инверсирующей его контент, превращающей новостные сводки в мифы, неудобоваримые для любого имеющего интеллект реципиента. В борьбе галлюцинаций и реальности, бреда и здравого смысла побеждает первый элемент этих бинарных оппозиций. Более того, он подается под видом новости, объективно освещающей реальность. Однако бессодержательность и бездоказательность таких «новостей» обнажают их действительную суть.

Ожесточение информационной войны наблюдается не только из-за вероломства мирового гегемона, но и вследствие самих особенностей эпохи, по наивности называемой информационной, но по здравому смыслу достойной наименования (псевдо)информационной - ведь она характеризуется как ростом информации, так и стремительным заполонением информационного пространства противоречащим истинным реалиям спамом (см.: Ильин, 2013, 2014, 2015). Некоторые аспекты этого «спанирования» информационной среды мы рассмотрели в данной статье. Те, кто пытаются оседлать глобализацию и выстроить мировой порядок по своим лекалам, не откажутся от этого «спанирования», от наступления на информационном фронте. Ведь залог их легитимности - в том, какое общественное мнение на глобальном уровне они создают в отношении к себе, своим покладистым союзникам и непокорным противникам. Проблема только в том, что «легитимирующий арсенал» иссякает, поэтому и создаваемая идеологическая картинка покрывается дырами, через которые все более и более проступает другое дно. Красивая картинка уже не может скрывать своего лживого содержания, и создаваемый ей мир иллюзий начинает все сильнее восприниматься в своем аутентичном виде - именно как мир иллюзий, а не реальности. Симулякр становится виден невооруженному глазу. Упразднение иллюзорной пропаганды в виде потери ею легитимности может прийти изнутри самой пропаганды, из ее очевидной слабости, объяснительной ригидности, интеллектуальной поверхностности, фактологической несостоятельности, наконец, откровенной лживости. Но, конечно, когда рупор постоянно говорит, что Россия - агрессор, рядовому слушателю, несколько раз в день на протяжении долгих лет слушающему этот тезис, будет трудно 
с ним не согласиться - даже если тезис не сопровождается никакими достойными обоснованиями. Тут следует вспомнить доктора Геббельса, утверждавшего, что если ложь будет услышана сто раз, она станет восприниматься как правда.

Американский медиарупор направлен практически на весь мир и потому его аудитория предельно широка. Остается только удивляться, насколько проектировщики (псевдо)информационного контента расписываются в неуважении к аудитории, если позволяют себе высказывать такой бред и ожидать, что публика воспримет его за чистую монету. Все-таки интеллект реципиента следует уважать... Однако, полагаю, высказанное пожелание - слишком недостижимое, неподъемное требование для этих деятелей. Ведь Россию обвинять не в чем, демонизировать ее на уровне фактологии не получается. Остается только мифология. Поэтому при реализации желания делегитимировать Россию по всем фронтам остается только продуцировать мифы и выдумки, да еще такие некачественные в смысле их обоснованности. И даже если найдутся непотребные факты о России, в условиях объективного функционирования медиасистемы они померкнут на фоне многочисленных уж явно не героических действий США на мировой арене.

Мировая история пестрит американскими преступлениями. Они - необозначенный, тшуательно скрыьаемый, неочененный, но настояший предмет гордости заправил американской (по сути глобальной) политики, их реальньх достижений. Аругой предмет их гордости - антиинформачионная риторика двойньх стандартов, изврашаюшая здравый смысл и минимальные требование к ответственности за сказанное. Истина многочисленных обвинений США $b$ адрес России состоит не $в$ их обоснованности, а, напротив, в их тотальной необоснованности.

Те правительства, которые воспринимают США в качестве «своих», рискуют оказаться в состоянии потери политического и экономического суверенитета. Если они его уже утратили, восприятие США как «своего» лишает их возможности Аля обретения суверенности и сохраняет статус-кво. В целях выражения не пророссийской, а именно своей, национальной, политической линии для многих стран мира важно как на идеологическом, так и на практическом (в политико-экономическом смысле) уровнях перевести в ранг «чужих» государство, которое выступает главным нарушителем норм мировой политики, которое стремится усиливать свое давление на стратегически важные регионы мира и расширять свою власть в глобальном смысле.

\section{СПИСОК АИТЕРАТУРЫ}

Бек, У. (2008) Космополитическое мировоззрение. М. : Центр исследований постиндустриального общества. 336 с.

Бжезинский, 3. (2013) Стратегический взгляд: Америка и глобальный кризис / пер. с англ. М. Аесятовой. М. : АСТ. 285, [3] с.

Бьюкенен, П. (2011) Зачем мы дразним медведя? [Электронный ресурс] // ИноСМИ.Ru. 29 августа. URL: http://inosmi.ru/usa/20110829/173957126.html (дата обращения: 22.02.2017).

В Аамаске заявили, что располагают записью переговоров военных США и ИГ (2016) [Электронный ресурс] // РИА Новости. 26 сентября. URL: https://ria.ru/syria/20160926/ 1477870854.html (дата обращения: 29.05.2017).

Гридин, И. (2016) Пентагон сожалеет об авиаударе по сирийской армии [Электронный ресурс]// РИА «Новый день». 18 сентября. URL: https://newdaynews.ru/inworld/579597.html (дата обращения: 14.05.2017). 
Аамаск заявил о наличии доказательств сотрудничества США и ИГ (2016) [Электронный ресурс]// Lenta.ru. 26 сентября. URL: https://lenta.ru/news/2016/09/26/accusation_coordination/ (дата обращения: 14.05.2017).

Аивеева, Ю. (2016) СМИ: Вашингтон намеревался передать сирийской оппозиции тяжелое вооружение [Электронный ресурс] // Комсомольская правда. 24 октября. URL: http://kp.ru/ online/news/2548434/ (дата обращения: 01.06.2017).

Аунаевский, И. (2016) СМИ: Белый дом обсуждал поставки оружия мятежникам для атак на ВКС РФ [Электронный ресурс]// Российская газета. Федеральный выпуск №7109 (241). 24 октября. URL: https://rg.ru/2016/10/24/smi-belyj-dom-obsuzhdal-postavki-oruzhiia-miatezhnikamdlia-atak-na-vks-rf.html (дата обращения: 02.06.2017).

Жижек, С. (2003) Война в Ираке: В чем заключается подлинная опасность? // Могос. № 1 (36). С. $75-88$.

Жижек, С. (2004) Ирак: история про чайник. М. : Праксис. 217, [2] с.

Иванов, И. А. (2012) Анатомия европейских ценностей // Современная Европа. № 2 (50). C. 13-23.

Ильин, А. Н. (2013) Проблема информационного консьюмеризма // Информационное общество. № 6. С. 22-28.

Ильин, А. Н. (2014) От информационной дезориентации к поверхностному потреблению информации // Информационное общество. № 5-6. С. 42-49.

Ильин, А. Н. (2015) Информационное общество и феномен скользящего консьюмеризма // Информационное общество. № 2-3. С. 59-67.

Киссинджер, Г. (1997) Аипломатия / пер. с англ. В. В. Аьвова ; послесл. Г. А. Арбатова. М. : Мадомир. 848 с.

Конашенков: Великобритания не сделала ничего для помощи сирийцам (2016) [Электронный pecypc] // Вести. 3 декабря. URL: http://vesti.ru/doc.html?id=2828668 (дата обращения: 26.04.2017).

Михайлов, И. (2008) Момент истины для России [Электронный ресурс]// Зиновьев. № 2 (3). C. 27-29. URL: http://zinoviev.org/chteniya/elzhur/moment-istiny/ (дата обращения: 22.06.2015).

Перкинс, А. (2005) Исповедь экономического убийцы. М. : Pretext. 319 с.

Стиглиц, Аж. (2005) Ревущие девяностые. Семена развала / пер. с англ. и примеч. Г. Г. Пирогова. М. : Современная экономика и право. 424 с.

США подготовили боевиков ИГИА, напавших на Ирак? (2014) [Электронный ресурс] // Вести. Экономика. 19 июня. URL: http://vestifinance.ru/articles/44076 (дата обращения: 28.05.2017).

Хантингтон, С. (2003) Столкновение цивилизаций / пер. с англ. Т. Велимеева, Ю. Новикова. М. : ООО «Издательство АСТ». 603, [5] с.

Хаос и экстремизм - оружие США на Ближнем Востоке (2014) [Электронный ресурс]// Вести. Экономика. 21 июня. URL: http://vestifinance.ru/articles/44098 (дата обращения: 03.06.2017).

Хомский, Н. (2014) Как устроен мир / пер. с англ. А. Ю. Кабалкина. М. : АСТ. 447, [1] с.

Энгдаль, У. (2009) Семена разрушения: Тайная подоплёка генетических манипуляций. СПб. : Нестор-История. 320 с.

Kolner Stadt-Anzeiger: Сирийские террористы признали, что за их спиной стоят США (2016) [Электронный ресурс] // Публикации.ру. 26 сентября. URL: http://publikatsii.ru/v-mire/10694k246lner-stadt-anzeiger-siriyskie-terroristy-priznali-chto-za-ih-spinoy-stoyat-ssha.html (дата обращения: 19.05.2017).

Brown, L. (2016) Russia is stopping aid reaching civilians under siege in Aleppo by not agreeing to a ceasefire, says Theresa May's spokesman [Электронный ресурс]// Daily Mail Online. December 1. URL: http://dailymail.co.uk/news/article-3988312/Russia-stopping-aid-reaching-civilians-siegeAleppo-not-agreeing-ceasefire-says-Theresa-s-spokesman.html (дата обращения: 19.05.2017).

Brzezinski, Z. et al. (1998) How Jimmy Carter and I started the Mujahideen / Z. Brzezinski, J. St. Clair, A. Cockburn [Электронный ресурс]// CounterPunch. January 15. URL: http://coun- 
terpunch.org/1998/01/15/how-jimmy-carter-and-i-started-the-mujahideen/ (дата обращения: 20.04.2017).

Brzezinski, Z. (2008) "I'd Do It Again". Talking about Afghanistan with Zbigniew Brzezinski / Z. Brzezinski, A. Garfinkle [Электронный ресурс]// The American Interest. Vol. 3, No. 5. May 1. URL: http://the-american-interest.com/2008/05/01/id-do-it-again/ (дата обращения: 18.05.2017).

Аата поступления: 3.06.2017.

Ильин Алексей Николаевич - кандидат философских наук, доцент кафедры практической психологии Омского государственного педагогического университета. Эл. адрес: ilin1983@yandex.ru

Ilyin Aleksei Nikolaevich, Candidate of Philosophy, Associate Professor, Department of Practical Psychology, Omsk State Pedagogical University. E-mail: ilin1983@yandex.ru

Аля иитирования:

Ильин А. Н. США: безответственная риторика и вероломная политика [Электронный ресурс] // Горизонты гуманитарного знания. 2017, №5. URL: http://journals. mosgu.ru/ggz/article/view/602 (дата обращения: Ад.мм.гггг.). DOI: 10.17805/ggz.2017.5.5 